\title{
O RAP, O HIP-HOP E O FUNK: A “ERÓPTICA” DA ARTE JUVENIL INVADE A CENA DAS ESCOLAS PÚBLICAS NAS METRÓPOLES BRASILEIRAS'
}

\author{
Mônica do Amaral
}

Resumo: A irreverência e a criticidade de alguns rappers e o gingar alegre do corpo erótico proposto pelo funk sugerem um novo cenário para as metrópoles do país, em que a pluralidade da arte juvenil surge como forma de enfrentamento das marcas deixadas por fraturas sociais profundas. Os conceitos de "visão dionisíaca de mundo", "estética extrema" e "transvaloração dos valores", de Nietzsche, e o "erotismo", segundo Bataille, nortearam o método de ruptura de campo, concebido por Herrmann. Este, essencial para se repensar as noções de autoridade e tradição na sociedade contemporânea a partir das ideias veiculadas pelo rap e pelo funk.Consideramos que somente uma etnografia do olhar que apanhe a dimensão erótica e irreverente - a "eróptica", segundo Canevacci - destas manifestações poderia nelas identificar uma estética afirmativa e crítica, como diria Nietzsche, capaz de produzir uma verdadeira reversão dos valores em nossa sociedade e, no caso, no interior da própria escola.

Palavras-chave: Culturas juvenis. Cultura escolar. Eróptica. Estética crítico-social.

1 Uma versão resumida deste trabalho foi apresentada na XI Reunión Nacional y IV Encuentro Internacional de Investigadores sobre Juventud, Havana/Cuba, realizado em fevereiro de 2009, sob o título:"El rap, el hip-hop y el funk:la eróptica del arte juvenil invade la escena de las metrópolis brasileñas". 


\section{Introdução}

Nossas pesquisas em algumas escolas públicas de São Paulo têm demonstrado a importância da escuta e de um olhar atento à diversidade étnica e cultural dos alunos, que deve ser contemplada por todo e qualquer projeto de renovação do ensino público deste país. A apreensão da dimensão histórico-cultural das culturas juvenis de protesto destas populações, cujas formas de expressão estéticas apresentam forte ressonância da diáspora afro-americana e afro-indígena-brasileira - uma dimensão pouco explorada pelos estudiosos das culturas juvenis, porém incansavelmente lembrada pelos rappers - do movimento hip-hop e do funk - e evidenciada pelas produções poético-musicais dos alunos-, permitiu-nos proceder ao rastrear intransigente do potencial crítico contido no marginal, no fragmento, no acessório, ou seja, das culturas que têm sido, senão negadas, negligenciadas pela cultura escolar.

A lacuna entre o passado e o futuro" considerada central por Hannah Arendt (1992) para se compreender o declínio da autoridade, assim como a perda de referência na tradição (greco-romana) da Civilização Ocidental " faz-se presente no espaço escolar, promovendo um verdadeiro descompasso entre as expectativas dos professores e as dos alunos, inclusive no que diz respeito ao significado da escola, que parece perder espaço em relação a outros meios propiciadores de formação para a atual juventude. Estamos nos referindo aqui a uma "formação" de outra ordem, propiciada pelo avanço no campo digital e eletrônico da indústria cultural hoje, a partir da qual os rappers têm promovido, no entendimento de um estudioso do jazz e do rap, Christian Béthune (2003), uma espécie de "telescopia histórica" ${ }^{2}$ das histórias não contadas das populações pobres - afro-indígenas-brasileiras - fazendo ressurgir nas rodas de canto falado ("ring shout") de algumas dessas culturas juvenis as dores da exclusão que se estendem a um passado esquecido, referente não apenas à diáspora afro-americana, mas também àquela que se fez presente nos inúmeros movimentos migratórios das regiões Norte e Nordeste para a região Sudeste neste país. De outro lado, por meio da dissonância musical produzida por um sofisticado aparato eletrônico, promovem efeitos de estranhamento estético, que expressariam a "consciência excluída da

2 Este termo foi empregado por Béthune (2003) para se referir às práticas de decomposição rítmica do rap, por meio das quais mistura estilos musicais os mais variados e promove uma espécie de recomposição melódica utilizando-se dos recursos da informática, o que torna possível reunir e discernir objetos e vivências distantes no tempo histórico. Aqui recorremos ao mesmo termo dando ênfase à recomposição de vivências históricas fragmentadas por meio de uma narrativa (o canto falado do rap) que, embora aparentemente presa ao presente, faz eco a um passado de opressão e de espoliação a que foram submetidos nossos descendentes afro-indígenas. 
sociedade" 3 .Termo empregado por Adorno (1975, citado por Habermas, 2002), para se referir à arte musical de vanguarda (referindo-se à música dodecafônica e atonal), reconhecida por esse importante filósofo alemão como portadora de potência crítica, ao qual recorremos para pensar a propósito de uma expressão musical contemporânea - o rap - que ao recorrer a frases melódicas de um único tom (portanto, mais próxima da música minimalista contemporânea) e uma narrativa direta, constituída de verdadeiros "atos de linguagem"4 escuta, sendo capaz de nos fazer entrar em contato, de outro modo, com a dimensão excluída da consciência social de nossa sociedade.

Em contraposição às imagens de violência e do erotismo beirando o grotesco, frequentemente associadas pela mídia às manifestações do hip-hop e do funk, buscamos demonstrar como essas, ao contrário do que é comumente veiculado, envolvem, na verdade, uma série de elementos estéticos capazes de produzir uma espécie de "reversão dialéti$\mathrm{ca}^{\prime \prime}$ da razão ordenadora totalizante, tal como tem sido imposto pela globalização da cultura. E levando esta última ao limite, finda por negá-la em seus aspectos reificadores. Queremos dizer, com isso, que o hip-hop, por exemplo, mimetiza em suas músicas a violência e o crime, chegando quase a sucumbir a estes, como única estratégia possível de denúncia da injustiça e da exclusão social a que são submetidos os jovens pobres e negros das metrópoles; enquanto o funk recorre a uma imagem "escrachada" da sexualidade, pondo a nu o que há de mais depreciativo sobre a muIher, como uma forma, justamente, de pôr em questão o machismo brasileiro; e o faz com o humor que lhe é característico, aliado à tonalidade agressiva e sensual de suas danças.

3 Esta é uma expressão utilizada por T.W. Adorno (1975), a propósito da brevidade das frases melódicas criadas por Schöenberg e Webern, que, segundo o filósofo alemão, expressariam não apenas a "densidade e consistência formais",em que não há lugar para o supérfluo, mas também a "consciência angustiada" do homem moderno. Depreende-se desta frase e do conjunto de suas reflexões sobre a "nova música" (dodecafônica e atonal), como o autor extrai sua teoria crítica da sociedade a partir da experiência estética singular, e com isso acentua a precedência do particular sobre o universal, do alegórico sobre o simbólico (cf. Habermas, 2002).

4 Trata-se de um termo empregado por Béthune (2003) para se referir ao caráter mimético e dramático da linguagem empregada pelos rappers. Estes, vociferando contra as injustiças, com tamanho realismo, acompanhados de todos os recursos sonoros para obter tal efeito, fazem com que, muitas vezes, suas músicas sejam confundidas com uma verdadeira incitação à violência e ao crime.

5 Estamos nos referindo ao termo empregado por Gatti (2009), para se referir ao traço fundamental do pensamento de W. Benjamin (1936/1980) sobre a arte de massa, que aponta para uma espécie de "dialética de distanciamento e aproximação,"de acordo com a qual o"pensamento aproxima-se mimeticamente de seu objeto de crítica, assimilando-se perigosamente a ele, até o ponto de sucumbir à sua força regressiva, como se essa fosse a única estratégia ainda disponível para sustentar um mínimo de distância crítica capaz de salvar suas potencialidades salvadoras" (Gatti, 2009, p. 299). 
Essas foram as principais ideias desenvolvidas a partir de ampla pesquisa de campo, dentro do Programa de Melhoria do Ensino Público ${ }^{6}$, realizada por cerca de três anos ininterruptos em uma escola pública, que atende a duas comunidades numericamente expressivas da região sul de São Paulo. Como resultado de um levantamento inicial, em que identificamos os problemas nevrálgicos em sala de aula e os interesses dos alunos, organizamos intervenções em sala de aula, feitas, de início, quinzenalmente, durante um mês e meio e, depois, durante todo um semestre - contando com a participação de professores e orientandos na preparação e na execução dessas intervenções.

Após essa experiência intensiva de trabalho conjunto com alunos e professores em sala de aula, identificamos a potência crítica do rapentre os garotos e de afirmação feminina que o funk assumira entre as garotas. Uma experiência que nos fez repensar nossos valores e que teve um impacto especial junto aos professores pesquisadores, no sentido de fazê-los repensar sua relação com os alunos e com o próprio conhecimento, o que acabou resultando em diferentes projetos de ensino/pesquisa, em que se procurou integrar os conteúdos das disciplinas, além de tomar em consideração o caráter de multipertencimento étnico e cultural dos alunos.

Envolveu, portanto, todo um trabalho de investigação empírica que permitiu a apreensão da riqueza e complexidade de uma escola pública com aquelas características (atendia a uma comunidade antiga, oriunda de uma região de Pernambuco, onde houvera, no passado colonial, uma política de aldeamento forçado entre sertanejos, ex-escravos forros e indígenas) e que acabou alimentando mais de uma dissertação de mestrado e minha própria tese de livre-docência, que ganhou o título:" $A$ Trama e a Urdidura entre as Culturas Juvenis e a Cultura Escolar: a 'Eróptica'como Método de Pesquisa e de Ruptura de Campo" (Amaral, 2010)7.

Nesta tese, demos ênfase a um método de pesquisa que fosse capaz de apanhar a dimensão erótica e irreverente de algumas culturas ju-

6 Sob o título Culturas Juvenis x Cultura Escolar: Como Repensar as Noções de Tradição e Autoridade no Âmbito da Educação? (Amaral, 2006, 2008), sob minha coordenação, que contou com a participação de: Tatiana Karinya Rodrigues (bolsista técnica, mestre pela FEUSP), Edson Yukio Nakashima (mestre pela FEUSP) e Maíra Soares Ferreira (mestre pela FEUSP) - estes últimos contaram com bolsa de mestrado da Fapesp; Luiz Abbonddanza, historiador e colaborador da pesquisa; e cerca de 14 professores da EMEF pesquisada, situada na zona sul de São Paulo, que foram contemplados com bolsas destinadas aos educadores-pesquisadores (EPII e EPIII).

7 Cito as três dissertações de mestrado defendidas na FEUSP a partir deste trabalho de pesquisa conjunta: A Metamorfose de Jovens Lideranças que Querem ser Professoras: Como a Escuta Analítica Propicia a Potência Crítica da Práxis (Rodrigues, 2008), Reatando as Pontas da Rama: a Inserção dos Alunos da Etnia Pankararu em uma Escola Pública na Cidade de São Paulo (Nakashima, 2009), A Rima na Escola, o Verso na História - um Estudo Sobre a Criação Poética e Afirmação Étnico-social entre Jovens de uma Escola Pública de São Paulo (Ferreira, 2010). 
venis cultivadas pelos alunos - com ênfase na estética do rap e do funkque nos pareciam sugerir um novo cenário para as metrópoles do país, em que a pluralidade da arte juvenil surgia como forma de enfrentamento das marcas deixadas por fraturas sociais profundas. Um olhar para o qual a escola não poderia permanecer alheia se quisesse propor um ensino significativo para os jovens daquela comunidade.

Nesse sentido é que consideramos que somente uma etnografia do olhar que apanhasse a dimensão erótica - a "eróptica", segundo Canevacci (2005b) - e irreverente destas manifestações poderia nelas identificar uma estética afirmativa e crítica, como diria Nietzsche, capaz de produzir uma verdadeira reversão dos valores em nossa sociedade e, no caso, no interior da própria escola.

Apoiados em ideias como essas e em alguns conceitos-chave, como a "visão dionisíaca de mundo", "estética extrema" e "transvaloração dos valores", defendidos por Nietzsche,e o"erotismo",como o concebeu Bataille, procuramos delinear as rupturas - conceitual e de campo - conforme definidas pelo psicanalista Fábio Herrmann, envolvidas na reconstrução das noções de autoridade e tradição na sociedade contemporânea a partir das tendências apontadas em particular pelo rap e pelo funk. Um trabalho de reflexão que pressupôs, de um lado, um recorte epistemológico que rompia com concepções totalizantes da teoria crítica da sociedade, constituindo-se em um esforço de aproximação da teoria estética da nova música sustentada por Adorno e a estética extrema de Nietzsche e Bataille; de outro, um olhar cortante e atento à infinidade de sentidos e perspectivas que se abriam na leitura das expressões estéticas dos alunos pesquisados em uma escola pública encravada entre duas favelas e os condomínios de luxo situados em um dos bairros mais ricos de São Paulo.

Ressalte-se que a construção do método não se fez apartada do objeto e envolveu uma experiência de teorização imanente que fosse além da própria coisa (cf.Goldman \& Adorno, 1975); por se tratar de intervenções em campo, envolvendo a subjetividade de alunos e professores pesquisadores, a ideia de ruptura de campo (Herrmann, 2001), sustentada pela teoria psicanalítica contemporânea, nos foi essencial para fazer emergir a "prototeoria"8 do sujeitos pesquisados.

Procurarei discutir, inicialmente a tessitura de nossa abordagem teórico-metodológica, de modo a explicitar como essa leitura das tendências contemporâneas das culturas juvenis foram se delineando ao longo da pesquisa.

8 Prototeoria foi um termo utilizado por Herrmann (2001) para designar a teoria feita sob medida para cada paciente, que no caso dessa pesquisa teria que se adequar às exigências de nosso objeto. Pareceunos essencial uma escuta atenta aos reclamos dos jovens, presentes em suas produções estéticas de protesto, a partir da qual construímos formulações teóricas fundamentais, a nosso ver, para se repensar a noção de autoridade do professor. 
2. A eróptica das culturas juvenis: uma ruptura possível na cultura escolar?

Massimo Canevacci (2005b), em seu artigo "Eróptica: etnografia palpitante para um olhar díspar", propõe uma espécie de etnografia do olhar que possa se abrir para o"sentir polissensorial",em que se articulam as dimensões estética e antropológica. Propõe o que denomina de "eróptica",uma espécie de conceito híbrido entre o olho e o erotismo. Aqui o autor toma como empréstimo as ideias desenvolvidas por Bataille em duas de suas obras - As lágrimas de Eros (1995) e História do olho (2003) - particularmente no que se refere à arte deste de proceder a uma espécie de leitura transdisciplinar do real - transitando entre a psicanálise, o surrealismo, a antropologia e a literatura - dando ensejo ao que Canevacci denomina de "olho participante" (em que o pesquisador se põe a olhar e, ao mesmo tempo, deixa-se olhar). O conceito de "eróptica", assim como de "olho participante", nos foram fundamentais tanto para repensar o modo de fazer pesquisa como na leitura das culturas juvenis, tão ricas em manifestações "polifônicas" e "policromáticas".

E é sob essa ótica que propomos que se considerem as "manifestações culturais juvenis" como uma espécie de prototeoria, por meio da qual se pode produzir uma "ruptura de campo" no plano da cultura, de modo a analisar as tensões da cultura escolar, que, imbuída de certo ativismo ideológico, na dupla face da psique do real (identidade e realidade), tem produzido como resultado apenas o seu distanciamento cada vez maior daquelas.

Mas explicitemos como foi possível a elaboração de uma prototeoria na medida do objeto a partir de um método que procuramos construir em consonância com aquele.

\section{Da construção do método em consonância com o objeto}

Com um olhar voltado para as tendências contemporâneas da cultura, cada vez mais fluidas, e de como estas se mesclam com nosso passado, cuja herança conserva os traços retrógrados que acompanharam desde o início o avanço do projeto de modernização brasileira, e outro, para a especificidade daquela escola pesquisada, procuramos delinear uma metodologia de análise dos questionários (aplicados a quatro classes de $7^{\text {a }}$ série e a três classes de $8^{a}$ série), não de acordo com uma abordagem quantitativa, mas segundo uma abordagem qualitativa inspirada no método psicanalítico.

A análise desses questionários se deu inspirada, inicialmente, no trabalho desenvolvido na área de psicologia e educação, por Milnitsky-Sapiro (2006), que propõe um método de análise do discurso, considerado 
pela equipe muito próximo do modo como pretendíamos abordar nosso objeto: no caso, o discurso do adolescente sobre a escola e suas vivências extraescolares (familiares, culturais), respeitando suas próprias concepções. Além disso, propõe formas bem interessantes de pesquisar o campo para se percorrer o entrelaçamento dos caminhos de cada sujeito com outros sujeitos, por meio de recortes do contexto social, como acreditamos ter feito na escola, realizando grupos de reflexão com os professores, entrevistas individuais com os mesmos, intervenções em sala de aula com a presença de alguns professores da equipe e, finalmente, aplicando um questionário junto aos alunos. A autora procura fundamentar sua metodologia de análise na teoria das representações sociais, sustentada por Jovchelovitch (2000), que, em seu artigo "Vivendo a vida com os outros: intersubjetividade, espaço público e representações sociais", defende uma ideia, fundamental para nossa pesquisa, envolvendo a apreensão da relação indivíduo-sociedade, afastada de qualquer compreensão psicologizante ou sociologizante. Uma concepção que, de acordo com o nosso ponto de vista, aproxima-se da que é sustentada por Theodor W. Adorno, em um belíssimo artigo, Sociology and Psychology $(1967,1968)$, em que o autor sustenta a necessidade de dialetizar as categorias intrapsíquicas psicanalíticas, de modo a apreender o modo como elas se comunicam com as categorias socioculturais, sem reduzir uma à outra, mas preservando a tensão entre os dois domínios. O objeto é tomado por Adorno como a nervura, o ponto em que a dialética se torna materialista. Em um debate com Lucien Goldman a propósito das relações entre a sociologia e a literatura, Adorno sustenta uma compreensão muito clara do que seja um pensador dialético: que no sentido rigoroso do termo não pode sequer falar de método "pela simples razão de que o método deve ser uma função do objeto e não o inverso" (Goldman \& Adorno, 1975, p.33).

Sem pretender realizar propriamente uma apreensão conceitual materialista em nossa pesquisa, porém inspirados por essa compreensão dialética da relação entre a teoria, o método e o objeto, procuramos nos acercar de um objeto, que se nos demonstrou como uma realidade bastante complexa - as relações entre os agentes escolares e os alunos de uma escola pública, e de como estes últimos, movidos por determinadas tendências das culturas juvenis, poderiam provocar uma "reversão dos valores" vigentes na cultura escolar a ponto de fazê-la repensar as concepções de autoridade e transmissão -, por meio de conceitos filosóficos, que pudessem conferir novos contornos ao objeto em sua realidade efetiva.

Tomando essas ideias como norteadoras de nosso trabalho de investigação, cuja abordagem teórico-metodológica se deu no sentido de respeitar as especificidades e complexidade de nosso objeto, e pensando especificamente na análise dos questionários, consideramos a pro- 
posta metodológica de Milnitsky-Sapiro bastante interessante e convergente com a ideia de Adorno de conferir o primado ao objeto, embora o tempo escasso que tínhamos para a análise não nos permitisse orientarmo-nos inteiramente por suas propostas. A autora defende basicamente que seja feita uma descrição de cunho etnográfico de modo a respeitar a linguagem da comunidade pesquisada sem partir de categorias temáticas a priori, mas, ao contrário, procurando depreendê-las do discurso dos sujeitos pesquisados, atentando para as"variações culturais, a partir da compreensão do significado da própria linguagem do grupo, buscando compreender seus significados no contexto" (Milnitsky-Sapiro, 2006, p. 5).Um registro etnográfico que seria feito tanto a partir de relatos de diário de campo, que, aliás, sempre nos acompanhou, como a partir dos depoimentos dos indivíduos cuja realidade estivesse sendo pesquisada.

Nossas leituras dos questionários e a escolha de categorias, a partir das quais reunimos as respostas e as interpretamos, foram feitas de um modo bastante rico e prolífero: fizemos a leitura das respostas dadas individualmente por cada aluno em voz alta para toda a equipe de professores; em seguida, anotávamos os comentários com base na experiência dos professores em sala de aula e a partir delas criávamos categorias e subcategorias de análise, evidentemente também informadas pelas leituras realizadas. $\mathrm{E}$, desse modo, fomos relatando nossa experiência de campo e escolhendo títulos para os itens relativos ao relato de campo que expressassem a imagem mais forte que ficara das leituras e comentários, como, por exemplo:"Da pintura de Brüghel à ordem imposta pelo tráfico", para exprimir a tensão entre a alegria de viver experimentada na comunidade e a violência do tráfico; "A regência das aulas diante de vozes tão dissonantes", sobre os desafios para se pensar as aulas diante da diversidade de interesses dos alunos;" Sobreviver no inferno...é possível?", referindo-se ao tema de um CD dos Racionais que remete às situaçõeslimite que podem levar um garoto pobre ao crime ("Se dirigem a mim como se eu não fosse nada / Eu só tinha 16 anos / Inteligência e personalidade... mofada / Humilhação na escola / A rua me atraía mais do que a escola");"Somos humildes, porém unidos!",expressão comum entre os alunos para dizer de sua força de união, apesar da miséria e preconceitos que os atingem. E outras frases por meio das quais procuramos exprimir o descrédito dos alunos em relação ao que lhes era oferecido pela escola: "A escola é um passatempo ou... uma perda de tempo?"," $A$ escola não é mais como antes... Disciplina é preciso, mas delatar colega, não!'," $A$ escola é carinho e educação... mas também dificuldades para ensinar e aprender","A fuga para a frente...em direção a um futuro melhor."Por fim, frases e imagens que expressassem o desenraizamento étnico, como:" São amigos do meu pai... o meu pai é Pankararu... e eu, quem sou?"; ou, ainda, uma frase musical que faz reviver o passado no presente, promovendo uma verdadeira "telescopia histórica" da diáspora africana, como o faz esta 
letra do rap"Castelo de Madeira", de Demis Preto:"Sou príncipe do gueto, só quem é, desce, sobe a ladeira..., meu castelo é de madeira" (cf. Amaral, 2007, 2008).

\section{Do método etnográfico pós-moderno ao método psicana- lítico de ruptura de campo: afinidades eletivas}

Acreditávamos, conforme foi sugerido anteriormente, que as "culturas extremas" (Canevacci, 2005a) juvenis poderiam se constituir em um"campo de possibilidades" para se repensar não apenas as formas de protesto juvenil nas metrópoles, mas o próprio processo de (des)construção das identidades dos adolescentes no mundo contemporâneo. Sustentávamos, ainda, que a etnografia do olhar "voltada para as manifestações eróticas polissensoriais da juventude" permitiria o surgimento de verdadeiras prototeorias capazes de se constituírem em momentos de ruptura de campo, a partir dos quais fosse possível construir elementos para se proceder a uma crítica contemporânea à razão reinante no universo escolar.

A partir dessa experiência de intervenção na rede pública de ensino " em que se entrelaçaram as experiências de professores pesquisadores, alunos, pais e pesquisadores da universidade (psicólogos, psicanalistas e alunos de pós-graduação com formação em Letras e História) " procuramos depreender um método de pesquisa capaz de articular: a "eróptica" de Canevacci, uma etnografia que combina o olhar e a dimensão erótica tal como sustentados por Bataille, e o método psicanalítico, tanto por meio da leitura flutuante de todo o material de campo, conforme sugerido por Milnitsky-Sapiro, como, no momento de nossas intervenções junto a alunos e professores, em que nos foi essencial a ideia de "ruptura de campo", defendida por Herrmann. A ideia de ruptura de campo foi concebida por Herrmann (2001) como algo imanente ao ato interpretativo e associado a um estado de irrepresentabilidade transitória, como condição do surgimento de novas representações que dariam corpo à prototeoria do sujeito. Uma concepção do método psicanalítico muito distante da interpretação simbólica da qual se vale a psicanálise freudiana, que envolve uma espécie de tradução do material recalcado.

Nossa intenção foi demonstrar, à medida que trabalhamos com o campo de "inconscientes relativos" 9 " resultante do entrelaçamento das subjetividades de professores, alunos e pesquisadores", como poderiam surgir "prototeorias" acerca das relações de sentido que se pode depreender das práticas e discursos produzidos no âmbito da sala de aula du- 
rante as intervenções, por meio de "atos analíticos",no lugar de sentenças interpretativas, a partir dos quais pretendeu-se promover mudanças na qualidade da comunicação entre professores e alunos.

A ideia era que a razão reinante na cultura escolar, sustentada por professores, coordenadores e direção da escola de Ensino Médio e Fundamental (respeitados seus diferentes matizes), pudesse ser rompida e renovada por dentro a partir do contato com o que há de mais crítico e transformador das culturas juvenis; estas, portadoras das vozes dissonantes e marginalizadas, concebidas pelos autores supracitados como potencialmente críticas.

\section{A construção de um olhar díspar em direção aos reclamos} dos jovens alunos

Nosso trabalho de pesquisa na referida escola pública aproximounos de algumas formas juvenis de manifestação cultural - como o hiphop e o funk - por meio das quais estes alunos pareciam alcançar uma verdadeira "virada criativa" em suas vidas apesar das circunstâncias precárias em que viviam. $E$, mais do que isso, conseguindo, assim, sair de seus "guetos"e se fazer escutar por diversos segmentos sociais até então alheios à realidade da população excluída das metrópoles.

Deparamo-nos, de um lado, com a irreverência e a criticidade de alguns jovens rappers, como se pode observar no trecho de uma música de autoria dos alunos - Realidade, não fantasia:

A falta de emprego e compreensão

Transporta o pivete pra uma vida de ladrão

A falta de emprego e compreensão

Mata os sonhos da pessoa e [os] joga

dentro do caixão

(Cesário, Diógenes, \& Gabriel, 2008).

Por outro lado, a irreverência que se traduz pelo gingar do corpo erótico: "Hip-hop, eu gingo... black, eu danço... rap, eu canto".

Encontramos, ainda, no depoimento de uma jovem, uma frase que aponta para a escola sonhada, em que o corpo, a música e o conhecimento andam juntos:"Eu sugiro que [a escola] tenha músicos e cantores, que nos ensinem a verdadeira música brasileira".

Sem contar o verdadeiro frenesi que acompanha as danças do ritmo funk, em que o erotismo feminino assume papel central, cujas letras e movimentos dos quadris sugerem e até mesmo lembram a sensualidade das danças afro-americanas, tanto sob o ritmo do jazze dos blues quanto 
do samba no Brasil. Ou mesmo a verve irreverente das letras do rap que evocam os desafios das emboladas e repentes nordestinos. Aliás, encontramos referências claras, no livro Poetas do Repente (2008), à proximidade entre as formas nordestinas do repente e as formas de improviso do rap, ressaltadas as diferenças com relação às bases rítmicas, o modo como rimam e de como organizam as estrofes.

Mensagens e imagens como essas nos sugeriram que as diversas formas encontradas por eles para se recriarem e superarem suas dores de exclusão passavam por uma estética musical refinada, inscrita, muitas vezes, no limiar da Lei, pondo em questão, muitas vezes, a moral cínica vigente, e por meio de um trabalho de recriação da cultura popular, apontavam para uma espécie de "inversão crítica dos valores", questionando, à semelhança do que propusera Friedrich Nietzsche, em Além do Bem e do Mal(1886/2001) e em Genealogia da Moral (1887/2005b), os "princípios a partir dos quais se fundam os valores" (Deleuze, 1962, pp. 5-6).Um clamor que mereceria a atenção não apenas dos educadores, mas do conjunto da sociedade.

No caso de nossa pesquisa na referida escola, pareceu-nos que os jovens estavam reivindicando ou mesmo recriando a cultura popular que se encontra, a um só tempo, enraizada nas origens "sertanejas" do homem rústico do nordeste brasileiro e combinada com a cultura afrobrasileira. No entanto, ao se depararem, nas metrópoles, com o duro retrato do homem pobre suburbano, viram-se impelidos a expressar suas angústias e anseios de satisfação por meio de raps e danças dotadas de aguçada potência crítica. Muitos deles fazendo emergir, com seus tambores, letras, músicas e danças, o que um dia Nietzsche chamara, em $A$ visão dionisíaca de mundo (1928/2005a), de o "cerne da força vital da humanidade". Justamente os elementos da cultura que foram há muito tempo expurgados da razão ocidental e, consequentemente, da razão ordenadora da escola.

Os raps (do movimento hip-hop) e o funk, embora inseridos no fenômeno da mundialização da cultura, tendem a negá-lo em seus aspectos reificadores ao assumirem uma atitude política de contestação (paradoxalmente, por meio de uma estética afirmativa) a todo tipo de discriminação e de exclusão social. Nesse sentido, nossa abordagem da estética do hip-hop, assim como do funk, como expressões musicais juvenis de protesto, procura ressaltar o que há de genuíno em suas produções (no sentido de dar vida aos jovens das classes populares no processo de estetização de si mesmos) e que escapam do esquematismo ${ }^{10}$ 
imposto pela indústria cultural, podendo fazer despertar, como diria Nietzsche (1872/2004), uma "educação estética" de outra ordem.

Revisitar Nietzsche, nesse sentido, cujo pensamento é considerado o divisor de águas que distingue o pensamento moderno e o pós-moderno, nos pareceu essencial:em particular, suas ideias críticas a respeito dos estabelecimentos do ensino e da cultura a ser transmitida às novas gerações; o empenho do desejo e das "afecções fortes" eliciadas pela filosofia dionisíaca que exercerão um papel fundamental em sua "metafísica do artista", bem como na genealogia da moral, a partir das quais proporá a"transvaloração dos valores" vigentes na modernidade. Destacamos, aqui, o caráter afirmativo de sua filosofia, inspirando-nos na concepção trágica do homem grego, a partir da qual pretendeu construir uma nova genealogia dos valores, ou seja, o valor dos valores, o que abriria a experiência humana a uma pluralidade de sentidos. Tanto o aspecto afirmativo que, segundo Deleuze (1962), estaria presente na "visão dionisíaca de mundo" sustentada por Nietzsche, quanto a ideia de "estética extrema", salientada por Heidegger (2007), foram-nos essenciais para uma interpretação conceitual afinada com o movimento histórico de nosso objeto, ou seja, as culturas juvenis por nós estudadas, a saber:o hip-hope o funk. Heidegger (2007), em suas preleções sobre Nietzsche (1888/2006), sustenta que o autor, a partir de $O$ Crepúsculo dos Ídolos, caminha menos no sentido de uma metafísica do artista (cf. Machado, 1984) e mais no sentido de uma "estética extrema",a partir da qual se evidenciou, para nós, a potencialidade crítica e afirmativa da estética étnico-juvenil do hip-hop e do funk, no âmbito escolar.

Foi pensando no distanciamento da escola pública em relação à multiplicidade de expressões da cultura juvenil que ficamos atentos, ainda, às observações de Bataille (1995), um importante intérprete de Nietzsche, de que a Filosofia deveria recuperar o poder de transgressão do erotismo e do próprio Nietzsche, de que se teria que ir ao encontro da mais viva expressão da Filosofia, que estaria presente na arte dionisíaca. Mas no que consistiria essa arte dionisíaca? A conjunção das diversas formas de expressão plástica do homem, tal como teria sido observado na Antiguidade, em que, associado ao canto, havia o gesto da dança, que se combinava com a potência da harmonia, da dinâmica e da rítmica, atingindo o êxtase sentimental na lírica e evocando imagens, como na epopeia, abrangendo, assim, o conjunto de todas as formas de expressão simbólica. A nosso ver, uma ideia muito próxima das formas de expressão estéticas afro-americanas, que de algum modo são retomadas pelo conjunto de

a de organizar os dados imediatos da consciência segundo as categorias do entendimento, substituindoa pelo "esquematismo" de acordo com o qual é pautada a produção e, desse modo, orientado as escolhas dos indivíduos. 
expressões artísticas do movimento hip-hop, em que se fazem presentes, como vimos, a dança, a música e outras formas de expressão plástica.

\section{O rap e o hip-hop: a presença de uma concepção dioni- síaca de mundo na arte juvenil de origem afro-americana?}

Béthune (2003), filósofo francês, amante e estudioso do jazz, em seu livro Le Rap - une Esthétique Hors de la Loi, realiza um estudo sobre as raízes históricas do rap, que o autor remete à música afro-americana (particularmente o jazz e o blues), que, por sua vez, tiveram inspiração na difícil trajetória percorrida pela população negra nos EUA, desde a escravidão, passando pela guerra de secessão, a depressão dos anos 30, entre outros momentos que marcaram a vida dessa parcela da população americana, cujo lamento fez-se sentir em suas músicas. Um passado que, segundo o autor, não desapareceu e, mais do que isso, encontra-se presente no estilo rap de música inaugurado pelo hip-hop americano. De outro lado, sustenta que esse estilo de música e de dança retoma a dimensão da arte inconsciente, brotada do povo, como dirá Nietzsche a propósito das obras dos grandes trágicos, Ésquilo e Sófocles, em seu livro $A$ visão dionisíaca do mundo (Nietzsche, 1928/2005a).

Sustentamos ainda que, na verdade, a inovação do-hip hop não se faz apartada da própria tradição da música de origem africana. Sendo esta uma das maiores contribuições do hip-hop: ao retomar uma arte plena, em que se combinam a expressão corpórea da arte, o canto marcado pela espontaneidade do improviso e da tradição oral, a dança e a música, que, por sua vez, enraizam-se na história dos americanos afro-descendentes. E com seu cântico de protesto, o hip-hop acabou se difundindo pelo mundo, particularmente entre os jovens pobres moradores das grandes metrópoles, e se combinando com novos campos culturais trazidos pelos excluídos de cada país e região do mundo.

No Brasil, o hip-hop chegou no início da década de 80 , através do break (dança), paradoxalmente trazido por agentes sociais pertencentes às camadas sociais mais ricas da sociedade. Mas foi Nelson Triunfo que, depois de entrar em contato com o break nas discotecas da classe média paulistana, levou o break e o hip-hop para o seu local de origem: a rua (cf. Contier, 2005).

Posteriormente, o break conquistou as ruas e as camadas dos excluídos sociais da cidade de São Paulo através da formação de grupos de dança, que se reuniam, num primeiro momento, na Praça Ramos, em frente ao Teatro Municipal, e num segundo, nas proximidades das galerias de lojas de discos da 24 de maio, esquina com a Dom José de Barros.

Os iniciadores desse movimento foram Nelson Triunfo, Thaide \& DJ Hum, MC/DJ Jack, Os Metralhas, Racionais MC's, Os Jabaquara Breakers, 
Os Gêmeos, entre outros. Muitos grupos musicais surgiram a partir dos fins dos anos 80. Em 1988 foi lançado o primeiro registro fonográfico de rap brasileiro através da coletânea "Hip-Hop Cultura de Rua" pela gravadora Eldorado. Desse disco, participaram Thaide \& DJ Hum, MC/DJ Jack, Código 13, entre outros grupos.

Vimos, portanto, que o hip-hop, com seu cântico de protesto, acabou se difundindo pelo mundo, particularmente entre os jovens pobres moradores das grandes metrópoles, e se combinando como novos campos culturais trazidos pelos excluídos.

Não se pode deixar de mencionar que sua proposta de crítica política faz-se presente não apenas na letra de suas músicas, mas por meio de uma estética inovadora e crítica de novo tipo. O rap, em particular, é feito da alternância entre uma circularidade rítmica e os cortes, o breakbeat, introduzido com o fito de promover deslocamentos dos equilíbrios musicais. A técnica do sampling, que consiste em selecionar diferentes arranjos musicais para introduzi-los em uma mesma composição musical, foi uma forma irreverente e transgressora de lidar com a absoluta falta de recursos financeiros para fazer música, o que remete o rap e o hiphop a uma longa tradição da música afro-americana, conforme assinalara acertadamente Béthune (2003). Mas o que há de inovador é a utilização da mais sofisticada tecnologia eletrônica de reprodução da arte musical - não como a música techno, que faz desaparecer os traços humanos para realizar o mixing de diferentes estilos musicais e fazer dessa alternância, bem como de uma poética rítmica marcada por rupturas, uma forma de humanizar a máquina (que os domina no trabalho e os marginaliza no campo cultural).

Segundo Béthune (2003), a arte conjugada do rap envolve uma estética bastante sofisticada:é uma forma lúdica de se fazer arte por meio de uma espécie de "telescopia histórica" (ou seja, uma forma de reunir e de discernir objetos distantes), de "deslocamento simbólico"e de "trituração sonora", que se opõe à tradição da cultura ocidental, que tende a valorizar a arte contemplativa e não a do“jogo em ação" (como é valorizado na cultura afro). Além dessa forma lúdica de lidar com os ritmos musicais, inventa palavras, em um jogo de vaivém, compondo uma nova relação entre o campo da oralidade e da escrita, revelando-se como uma verdadeira "linguagem em ato",com toda sua expressividade quase que teatral, de natureza polifônica e polissensorial que a acompanha. Para denunciar os abusos da polícia, por exemplo, ou a discriminação, muitas vezes os rappers recorrem a esses "atos de linguagem", vociferando contra as injustiças, com tamanho realismo, acompanhado de todos os recursos sonoros para obter tal efeito, que, muitas vezes, suas músicas são confundidas com uma verdadeira incitação à violência e ao crime. Segundo Béthune,"o rapper não fala da realidade, ele fala na realidade e, colocan- 
do-se no coração da ação, ele transforma fortemente sua fisionomia" (Béthune, 2003, p.59).

\subsection{Os rappers - os novos cronistas da modernidade}

Contier (2005) considera que os rappers são os novos cronistas da sociedade brasileira, a qual se encontra marcada pela estranha combinação do arcaico e do moderno, em que o papel civilizador da revolução burguesa jamais se estendeu ao conjunto da sociedade e está ainda hoje muito longe de fazê-lo:

O rap caracteriza-se pela reinvenção do cotidiano através da oralidade de pessoas comuns... Os rappers narram com as suas próprias vozes e olhares o cotidiano das cidades contemporâneas transfigurando-se em instigantes cronistas e críticos da modernidade. Retratam a periferia de São Paulo num momento de intensa globalização e da formação de uma sociedade marcadamente massificada. (Contier, 2005, p. 5)

Analisemos mais de perto, iluminados por essas ideias, como poderia ser reinterpretada a letra da música Realidade, não fantasia, apresentada no início como uma forma de luto de uma infância que mal pode ser sonhada subjacente à realidade avassaladora que "mata os sonhos da pessoa" e como os espaços propiciados na escola e na comunidade para se recriarem por meio do rap e do hip-hop e acabaram permitindo o surgimento de uma "estética no limiar da Lei", capaz de oferecer sustentação psíquica e cultural sobretudo para os garotos pobres das metrópoles.

Se formos analisar o rap dos garotos, Realidade, não fantasia, temos um exemplo típico de reinvenção da linguagem:"É inadmirável uns trutas da quebrada fazendo 157 ou seja assalto a mão armada". Produz-se, como resultado, uma verdadeira reinvenção da linguagem materna, nela introduzindo uma espécie de linguagem estrangeira, resultando em uma forma interessante de se reapropriar da mesma, sobretudo para aqueles que são excluídos da linguagem culta e que são normalmente considerados incapazes de enveredar pela arte poética.

As flutuações de significados ou mesmo a ambiguidade, entre o experimentado socialmente e a arte poética enquanto tal, tem gerado uma série de ingerências jurídicas e policiais contra os grupos de rap do movimento hip-hop, o que exige, segundo o autor, mais do que nunca, uma abordagem estética de tais manifestações, cujos sentidos podem ser apreendidos se observarmos a particular dialética que se estabelece entre o novo e o tradicional em suas criações:"segundo a maneira como integram, transgredindo, a base tradicional de onde provêm" (Béthune, 2003, pp. 15-16). 
E isso pode ser pensado tanto a propósito da estética musical do rap que traz consigo algo da cultura afro-americana, ou seja, os desafios e lamentos em forma de cânticos presentes no jazz, blues e até no soul e funk, como do repente e cantorias praticadas no Nordeste brasileiro, que contam as histórias do povo sofrido do sertão. Uma estética que é capaz ainda de combinar o universal e o particular, em sua crítica social, como podemos observar noutro trecho do rap dos garotos: "Pra vencer na vida é preciso ser agressivo, somos grupo elementos". E depois o refrão que remete a uma questão social mais ampla: "A falta de emprego e compreensão / transporta o piveti pra uma vida de ladrão / a falta de emprego e compreensão / mata os sonhos da pessoa e [os] joga dentro do caixão". Mas a transgressão se faz presente também no trecho que aponta para o limiar do crime e da transgressão, ao mesmo tempo em que exige um olhar atento da sociedade, assim como o direito de passagem dos jovens pobres das metrópoles: "A lei do mata mata é o poder que abre as portas / Essa é a lei de satanás quem não tem respeito faz / Com uma arma na cintura vc vê quem pode mais". E o apelo não apenas para a compreensão, mas para que os vejam com humanidade: "Somos manos de direito e ainda temos esperança".

É exatamente a situação dessa população excluída desde os tempos idos coloniais que os rappers, com sua estética agressiva denunciadora, e os funkeiros, de modo mais irônico e alegre, têm denunciado em suas músicas.

Façamos um parêntese, introduzindo um momento do trabalho de campo em sala de aula com os alunos, para que se tenha uma ideia do significado dessa "linguagem em ato" adotada pelo rap, a qual de algum modo fora adotada por nós nas intervenções em classe com aquelas crianças, para que nos fosse possível adentrar em suas vivências, escutá-las e fazê-las nos escutar.

\section{Contra a arma dos traficantes e da polícia... resta-nos a arma da música}

Essa frase surgiu em um de nossos debates acirrados em torno da questão da violência no bairro, em uma sala de aula com alunos da $7^{a}$ série, um pouco antes de chegar a equipe de reportagem da TV Record, que veio à escola interessada em filmar os grupos de rap.

Depois de iniciado o debate, muitos garotos salientaram a questão da injustiça para com os pobres, cometida inclusive por parte da "Justiça", mas principalmente pela polícia, que eles voltaram a chamar de" coxinha" e de "gambé" (expressões também utilizadas pelos Racionais). Como alguns alunos começassem a simular o gesto de atirar com uma arma de fogo, procurei entrar no clima da dramatização de uma situação real, per- 
guntando-Ihes:" Quem está machucando quem? Quem quer matar quem? Ei, mas... só existe essa solução?'.Enfim, procurei fazê-los refletir sobre como poderiam se defender, seja da violência policial, seja dos traficantes, por outros meios, sem recorrer necessariamente às armas de fogo. Responderam que sim, que existiam outras formas. Nesse momento, alguém cochichou para mim que os policiais entravam na favela correndo com arma atrás dos traficantes e que estes, também armados, para se defender, entravam na rua no meio de um grupo de crianças... E que tudo isso era muito perigoso. Eu lhes disse que uma situação de violência como a enfrentada por eles em seu dia a dia não era justa e muito menos legal, que significava mesmo um abuso de poder, mas que os Racionais pareciam se utilizar de outro tipo de arma para denunciar tal situação. À minha pergunta a respeito de qual era essa arma, um garoto respondeu: " $A$ música!" 11

Evidenciou-se, nesse momento, no entanto, quão difícil era, para esses jovens, aderir"pra valer"a esse discurso dos Racionais, uma vez que a violência experimentada por eles todo dia era tão absurdamente desproporcional, representando um verdadeiro atentado à cidadania e à infância, que ficava difícil responder apenas com um discurso crítico de denúncia. Daí o provável recurso desses rappers mais engajados, considerados, como vimos, por alguns autores (Contier, 2005), como os "novos cronistas das metrópoles", a verdadeiros "atos de linguagem".

Esta e outras experiências em sala de aula, que nos remeteu ao"coração da cena"- pessoal, histórica e politicamente, do mesmo modo como os rappers fazem em suas músicas -, nos fez pensar sobre a importante contribuição do hip-hop para a educação pública, como o demonstra um professor norte-americano, Marc Lamont Hill (2009), que recorre ao rap como parte fundamental das estratégias de ensino de literatura. $O$ autor salienta como os jovens exigiam o comprometimento pessoal do professor, na realidade, para que aderissem "pra valer" à proposta de trabalho. Foi o que sentimos nesse momento da intervenção: diante da falta de compromisso do conjunto da sociedade com a verdadeira universalização dos direitos sociais, culturais e políticos, era preciso"ver pra crer" se os adultos que ali se encontravam estavam realmente dispostos a levá-los a sério, o que implicaria um compromisso que iria além do âmbito da sala de aula.

4. E o funk carioca - um produto massificado ou uma estética erótica irreverente de novo tipo?

Nosso interesse pelo funk surgiu motivado por nossa pesquisa na mesma escola pública em São Paulo onde nos deparamos com os jovens

11 Mais uma vez aqui, apresentamos uma forma de interpretar, pela via da dramatização, que denominamos "atos analíticos" para diferenciar da "sentença interpretativa". 
rappers mencionados anteriormente. Depois de uma série de trabalhos realizados em classe, em que estimulávamos os alunos a expressarem suas ideias a respeito da escola e de suas vidas, seus sonhos e as dificuldades para alcançá-los, e ainda sobre músicas e danças apreciadas e cultivadas por eles nos finais de semana, encontramos muito interesse em torno das músicas e danças afro-brasileiras, dentre elas o hip-hop e o funk.

No final do ano, programamos uma apresentação de alguns grupos de música e de dança, e como havia uma expectativa de realizarmos um baile funk no final, apesar de nossa insistência, os alunos não trouxeram seus pais, quase que deliberadamente. Somente depois fomos entendendo seus motivos. Eram alunos da última série do Ensino Fundamental e muitos deles pareciam decepcionados/desencantados com as arbitrariedades e com o descaso com sua formação por parte da direção daquela escola. Por esse e outros motivos, o que valia mesmo naquele momento era o prazer e a "liberação total". Nas apresentações de seus textos de despedida foram até mesmo saudosistas, mas quando apresentaram seus raps, bastante contestadores e, depois das meninas com seus dois números de funk, o ambiente ficou praticamente incontrolável, prevalecendo uma excitação claramente de tonalidade sexual.

Embora muitos professores tenham se assustado diante do que consideraram "uma sensualidade/sexualidade sem limites", beirando "o desrespeito ao ambiente da escola", o que presenciamos, na verdade, foi o clamor dos alunos para serem ouvidos e vistos. E (por que não?) também acompanhados pelos adultos em suas expressões juvenis.

O documentário sobre o funk carioca, Sou feia, mas tô na moda, sob a direção de Denise Garcia (2007), conferiu a todos nós, professores e pesquisadores, novas chaves de leitura para aquela sensualidade irreverente e provocativa das garotas da escola. As cantoras de funk enfatizaram, em seus depoimentos, a importância do funk sensual, em primeiro lugar, no sentido de impedir a violência como prova de virilidade - que ameaçava a continuidade dos bailes funk nos morros cariocas -, incentivando, ao contrário, o amor sexual/sensual entre os sexos; em segundo lugar, como forma de as mulheres se imporem aos homens, dos pontos de vista da liberação sexual feminina e a favor dos direitos de independência da mulher das classes populares, como parte de uma espécie de "movimento popular feminista". Do mesmo modo que as jovens cantoras do funk, na sua maioria negras, davam o seu testemunho sobre a importância do "funk sensual" para a liberação feminina, vimos nas apresentações de funk na escola e noutros momentos em que fomos convidados para dançar com as alunas, um modo de se apropriarem de seus corpos sensuais e de se comprazerem dos efeitos de sedução produzidos nos garotos. E, claro, mais uma vez éramos convidados a experimentar "pra valer" aquela liberação, não apenas no nível discursivo, mas com nossos corpos sendo atravessados por seus ritmos sensuais. 
Depois, lendo o livro de Micael Herschmann (2005) O Funk e o HipHop Invadem a Cena, tivemos a oportunidade de conhecer o funk carioca e suas vicissitudes. Como o próprio título sugere, o livro refere-se ao modo como tais culturas juvenis reinscrevem os jovens pobres e negros no espaço público das grandes cidades, do qual são usualmente excluídos.

A posição do autor, ao contrário do que se tem dito a respeito do funk carioca, é a de que o fato de o funk ser mais alegre e erotizado não quer dizer que seja alienado ou apolítico. Salienta a importância do lançamento do disco do DJ Marlboro, em 1989, do Funk Brasil n. 1, responsável pela nacionalização da música e pelo lançamento dos jovens pobres e marginalizados das metrópoles no cenário midiático que, por meio deste, alcançou popularidade, fazendo com que o público de classe média, inclusive, tivesse acesso a essa realidade.

\section{Da estética irreverente à elaboração de um luto tornado possível através da música de protesto e da dança erótica}

Em primeiro lugar, a virada criativa desses jovens, que souberam fazer de suas vidas, frente a uma situação de tamanha fragilidade do tecido social, consistiu em quê exatamente?

Em conseguir converter a exclusão em arma de denúncia e em motor para a construção de uma estética de novo tipo? Como dizia Canevacci (2005b), é preciso ser capaz de olhar para essas manifestações dos jovens que usam seus corpos e suas mentes para penetrar no que há de mais alienado e fazê-lo explodir por dentro. Eis a nova estética, que no caso do jovem pobre passa por uma estética "hors de la loi",como sustentara Béthune (2003), que parece apontar para uma nova ética e a consequente necessidade de "refundar" o conjunto dos valores de nossa sociedade.

Segundo os autores de Cabeça de Porco (Soares, Bill, \& Athayde, 2005),"aquilo que na cultura hip-hop se chama atitude talvez seja a síntese de uma estética e de uma ética, que se combinam de modo muito próprio na construção de uma pessoa" (p. 206). Os autores estão querendo dizer que suas músicas exigem o reconhecimento e a generosidade do olhar do outro, ou melhor, do conjunto da sociedade para esses jovens que vêm sendo excluídos da condição de cidadãos. Daí a importância da proposta de Marc Lamont Hill (2009), da Universidade de Columbia, envolvendo uma proposta de pedagogia crítica no ensino médio a partir do rap, como forma de instaurar o que considerou ser uma "política da identidade": por meio das storytelling (contação de histórias de si e da comunidade) compartilhadas em grupo e cujo mote era dado por trechos selecionados de letras de rap, promovia-se o que denominou de 
wounded healers (cicatrização de feridas) socio-históricas herdadas da diáspora dos afrodescendentes e do verdadeiro apartheid social e cultural ainda não inteiramente superado na sociedade americana e, claro, menos ainda em países como o nosso, em que a desigualdade social é uma das mais sérias do mundo.

Consideramos, ainda, que o funk, de um modo mais irônico e alegre, e muitas vezes debochado, vem impondo a necessidade de um novo olhar para as mulheres negras e pobres das metrópoles, que sofrem não apenas com a exclusão social e a violência do tráfico e da polícia, mas com o machismo brasileiro que se constitui em outro tipo de violência que não pode ser negligenciada. Sua estética sensual/sexual põe em questão os valores que têm regulado a tradição familista patriarcal e escravocrata presente de modo opressivo, sobretudo nas relações entre os gêneros das famílias de baixa renda no Brasil.

\section{A título de conclusão:}

Nossa pesquisa iniciou-se movida pelas inquietações trazidas por Hannah Arendt (1992) quanto aos rumos da educação a partir do momento em que a transmissão da cultura se viu ameaçada pela ruptura do presente com os lastros do passado, deixando de ter como referência a tradição greco-romana, na qual teriam se ancorado as instituições democráticas da civilização ocidental. Todos esses fatores contribuíram para fazer ruir a autoridade pública, atingindo as instituições pré-políticas, como a família e a escola, ao mesmo tempo em que representavam séria ameaça à conservação do patrimônio cultural. Com isso, colocaram-se em risco os "fundamentos do mundo" e, consequentemente, as condições de sua preservação.

Essa lacuna entre o passado e o presente que, na escola pesquisada, traduziu-se pelo descompasso absoluto entre a cultura escolar e o que denominamos de culturas juvenis, parecia ameaçar o pouco que restava da autoridade do professor, comprometendo seriamente as possibilidades de transmissão docente. Uma cultura escolar que, ao renunciar à sua autonomia, ficava à mercê das "novidades" político-pedagógicas impostas pelo Estado e cada vez mais distanciadas dos reais interesses e necessidades dos jovens pobres, moradores das comunidades adjacentes aos polos de concentração da riqueza da metrópole de São Paulo. De outro lado, encontramos jovens ávidos por se recriar e se impor ao mundo dos adultos e à cidade excludente onde moravam. E assim o fizeram por meio da música e da dança, exigindo o direito de estetizarem por si mesmos, tal como sugerira Nietzsche ser a verdadeira tarefa da educação. Os professores, por sua vez, depois de três anos de pesquisa e de reflexão sobre suas práticas de transmissão e de contato íntimo com as culturas juvenis 
cultivadas pelos alunos da escola, passaram a exigir maior autonomia para decidir sobre o conteúdo de suas aulas e os métodos de ensino.

Em uma escola onde reinava o caos e a falta de acolhimento dos anseios dos alunos e mesmo dos pais desses alunos, nossas intervenções deram vida, por meio das expressões plásticas e musicais dos alunos, ao olhar abafado dos professores sobre sua própria realidade de trabalho, ao mesmo tempo em que colocava em relevo a realidade dos alunos daquela comunidade encravada no seio de um dos bairros mais ricos e luxuosos da capital.

As expressões polissensoriais dos adolescentes que se manifestavam de modo caótico e barulhento ganharam sentido diante deles mesmos, ao começarem a substituir o verdadeiro solilóquio em que muitos deles se encontravam mergulhados por raps, os mensageiros de protesto dos jovens pobres das metrópoles. E as garotas, com sua sensualidade irreverente, exigiram, de todos, um olhar atento - e o direito a terem um espaço para seu "ser mulher" - que fosse capaz de ver nelas o avesso do que diziam as letras funks que tocavam ao fundo, cujas letras pareciamnos degradar a imagem feminina. Para compreender o modo como esses jovens se apropriavam do que era veiculado pela mídia, transformandoo em seu contrário, foi-nos fundamental a ideia de "reversão dialética", segundo a qual, de acordo com a leitura feita por Luciano Gatti (2009) das ideias de Walter Benjamin (1936, 1980), é possível interpretar a potencialidade crítica da cultura na era da reprodutibilidade técnica. Esse sentido da crítica pode ser depreendido, como vimos, das letras de alguns rappers, como os Racionais MC's, que se deixam praticamente levar pela regressão induzida pela mídia para revertê-la em seu contrário promovendo a educação de massas de jovens das periferias das metrópoles e, desse modo, assumindo o caráter político do movimento.

$E$, assim, os jovens alunos, com sua estética "crítico-destrutiva" $e$ "positivo-afirmativa"12 - ou "extrema", na versão heideggeriana -, atingiram em cheio o coração da escola, que há muito não os escutava - ou seja, a burocracia, a direção e até mesmo os professores (a maioria só vinha pensando em remoção e aposentadoria). Os professores, por sua vez, tiveram a oportunidade de ressignificar suas experiências e, sentindo-se apoiados, intelectual, emocional e politicamente, reassumiam a autoridade ameaçada, porém, noutros moldes.

Evidenciou-se para todos nós - pesquisadores da universidade e professores-pesquisadores - a pertinência de recorrer a um método que se abre, de acordo com a releitura feita por Maximo Canevacci (2005b) de Bataille, para o olhar participante de Eros - que olha e se deixa olhar - e

12 Na verdade, inspiramo-nos nas duas vertentes de análise de acordo com as quais, segundo Giacóia (2005), Nietzsche teria destruído os pilares da metafísica ocidental. 
assim é invadido pela experiência do desconhecido e,em contato íntimo com este, torna possível refundar a autoridade.

Mas, por que a aproximação de autores que, embora mantenham algumas "afinidades eletivas", mantêm orientações epistêmicas não coincidentes?

O debate teórico ensejado por todas essas questões suscitadas pela pesquisa de campo foi muito enriquecedor, assim como a leitura de Nietzsche e Bataille, que nos impulsionou a percorrer diferentes interpretações e confrontações teóricas, procurando, desse modo, levar a sério o perspectivismo nietzschiano. Acreditamos, ainda, que esta leitura aberta, inclusive, para novas interpretações, possa subsidiar um projeto de mudança "radical" a ser implementado no sistema público de ensino, se não quisermos perder a oportunidade de formar as novas gerações.

Rap, hip-hop and funk: the "eroptica" of youth art invades public schools scenario in Brazil's metropolis

Abstract:Some rappers' irreverence and criticality and the happy erotic body swinging as proposed by funk, suggest a new scenario for Brazil's metropolis, where the youth art plurality comes up as a way to face the trace left by deep social fractures. The concepts of the "Dionysian vision of the world","extreme aesthetics" and "revaluation of values", as defended by Nietzsche, and "eroticism", as conceived by Bataille, guided the method of "rupture of field", as defined by Herrmann. This one, essential to reconsider the notions of authority and tradition in the contemporary society, throughout the trends shown, particularly by rap and funk. Only ethnography of the regard which captures their irreverent erotic dimension - the "eroptica", according to Canevacci - seems to be able to identify in them an affirmative and critical aesthetics, as Nietzsche would say, able to produce a true reversal of values in our society.

Keywords: Youth cultures. School culture. Eroptica. Social critical aesthetics.

Le rap, le hip-hop et le funk: l' «éroptique» de l'art des jeunes envahit la scène des écoles publiques dans les métropoles du Brésil

Résumé: L'irrévérence et le ton critique de certains rappers et le gai balancement du corps érotique proposé par le funk suggèrent la perspective d'un nouveau scénario pour les métropoles du Brésil, où la pluralité de l'art des jeunes surgit comme moyen 
de faire face aux marques laissées par de profondes fractures sociales. Les concepts de "vision dionysiaque du monde ", d' " esthétique extrême » et d'un « par-delà les valeurs reçues » de Nietzsche, ainsi que l'« érotisme » selon Bataille, ont servi de guide à la méthode de "rupture de champ » conçue par Herrmann, essentielle pour que soient repensées les notions d'autorité et de tradition dans la société contemporaine à partir des idées véhiculées par le rap et par le funk. Seule une ethnographie du regard qui capte la dimension érotique - «l'éroptique», selon Canevacci - et irrévérente de ces manifestations, peut reconnaître en elles une esthétique, capable, comme le dirait Nietzsche, d'opérer un véritable renversement des valeurs dans notre société et, dans le cas, à l'intérieur même de l'école.

Mots-clés: Cultures des jeunes. Culture de l'école. Éroptique. Esthétique critique et sociale.

El rap, el hip-hop y el funk: la "eróptica" del arte juvenil invade la escena de las metrópolis brasileñas

Resumen: La irreverencia y el pensamiento crítico de algunos "rappers" y el "gingar" alegre del cuerpo erótico propuesto por el funk, ambos cultivados en la periferia de las grandes ciudades brasileñas, sugiere un nuevo escenario para las metrópolis del país, donde la pluralidad del arte joven aparece como forma de confrontación de las marcas producidas por "fracturas sociales profundas".Los conceptos de "visión dionisíaca del mundo","estética extrema" y "transvaloración de los valores", de Nietzsche,y el "erotismo", según Bataille, nortearon el método de ruptura de campo, concebido por Herrmann. Éste, esencial para repensarse las nociones de autoridad y tradición en la sociedad contemporánea a partir de las ideas vehiculadas por el rap y por el funk. Solamente una etnografía de la mirada que capture la dimensión erótica e irreverente - la "eróptica", como sugiere Canevacci - de estas manifestaciones podría identificar en ellas una estética afirmativa y crítica, como diría Nietzsche, capaz de producir una verdadera reversión de los valores en nuestra sociedad y, en nuestro caso, en el interior de la propia escuela.

Palabras clave: Culturas juveniles. Cultura escolar. Eróptica. Estética crítico-social. 


\section{Referências}

Adorno, T.W. (1985). Dialética do esclarecimento. Rio de Janeiro:Zahar.

Adorno, T.W. (1974). Filosofia da nova música. São Paulo: Perspectiva.

Adorno, T.W. (1967). Sociology and psychology (part I). New Left Review, 46, 6781.

Adorno, T.W. (1968). Sociology and psychology (part II). New Left Review, 47, 7997.

Amaral, M. do. (2006). Culturas juvenis $X$ cultura escolar: como repensar as noções de tradição e autoridade no âmbito da educação? Projeto de Pesquisa apresentado ao Programa "Melhoria do Ensino Público", FAPESP, São Paulo. (Trabalho não publicado)

Amaral, M. do. (2007). Relatório Científico Parcial do Projeto de Pesquisa Culturas Juvenis $X$ Cultura Escolar: como repensar as noções de tradição e autoridade no âmbito da educação? São Paulo. (Trabalho não publicado)

Amaral, M. do. (2008). Relatório Científico Final do Projeto de Pesquisa Culturas Juvenis X Cultura Escolar: como repensar as noções de tradição e autoridade no âmbito da educação? São Paulo. (Trabalho não publicado)

Amaral, M. do. (2009). El rap, el hip-hop y el funk: la eróptica del arte juvenil invade la escena de las metrópolis brasileñas. In Anais da XI Reunión Nacional y IV Encuentro Internacional de Investigadores sobre Juventud (Versão em CD). Habana: Centro de Estudios sobre la Juventud.

Amaral, M. do. (2010). A trama e a urdidura entre as culturas juvenis e a cultura escolar: a "eróptica" como método de pesquisa e de ruptura de campo. Tese de Livre Docência, Faculdade de Educação, Universidade de São Paulo, São Paulo.

Arendt, H. (1992). Entre o passado e o futuro. São Paulo: Perspectiva.

Bataille, G. (1995). Les larmes d'Éros. Paris: Jean-Jacques Pauvert.

Bataille, G. (2003). História do olho. São Paulo: Cosac \& Naif.

Benjamin, W. (1980). A obra de arte na época de suas técnicas de reprodução. In Textos escolhidos - W. Benjamin, M. Horkheimer, T. W Adorno, J. Habermas (Coleção Os Pensadores, J. L.Grünnewald, trad.,pp. 3-28). São Paulo:Abril Cultural. (Trabalho original publicado em 1936) 
Béthune, C. (2003). Le rap - une esthétique hors de la loi. Paris: Autrement.

Canevacci, M. (2005a). Culturas eXtremas - mutações juvenis nos corpos das metrópoles. Rio de Janeiro: D. P. \& A.

Canevacci, M. (2005b). Eróptica: etnografia palpitante para um olhar díspar. Revista IDE, 41, 91-96.

Cesário, Diógenes, \& Gabriel. (2008). Realidade, não fantasia! (Folheto de versos, pp. 29-30). São Paulo: Gráfica da FEUSP.

Contier, A. D. (2005). O rap brasileiro e os Racionais MC's. In Anais do 1 Simpósio Internacional do Adolescente. São Paulo: Faculdade de Educação da Universidade de São Paulo. Recuperado em 03 de fevereiro de 2006, da SciELO (Scientific Eletronic Library Online), www.proceedings.scielo.br/sci

Deleuze, G. (1962). Nietzsche e a Filosofia. Porto: Rés.

Denis Preto Realista (Intérprete).(2004).Castelo de madeira.In A Família, Cantando com a alma. São Paulo:Sky Blue Music.

Duarte, R. (1978). Esquematismo e semiformação. Revista de Ciências da Educação, 1(1), 441-457.

Duarte, R. (2007). Sobre o constructo estético-social. Revista Sofia, 11(17/18), 239263.

Ferreira, M. S. (2010). A rima na escola, o verso na história - um estudo sobre a criação poética e afirmação étnico-social entre jovens de uma escola pública de São Paulo. Dissertação de Mestrado, Faculdade de Educação, Universidade de São Paulo, São Paulo.

Garcia, D. (Diretor). (2007). Sou feia, mas tô na moda [DVD (61 min., color.)]. Brasil: Imovision.

Gatti, L. (2009). Constelações - crítica e verdade em Benjamin e Adorno. São Paulo: Loyola.

Giacóia, O. (2005). Nietzsche \& Para além de bem e mal. Rio de Janeiro:Jorge Zahar.

Goldman, L., \& Adorno, T. W. (1975). Discussion extraite des actes du Second Colloque International sur la Sociologie de la Littérature tenue à Royaumont. In Lucien Goldman et la Sociologie de la Littérature: Hommage à Lucien Goldman (pp. 33-50). Bruxelles: Éditions de L'Université de Bruxelles. 
Habermas, J. (2002). O discurso filosófico da modernidade. São Paulo: Martins Fontes.

Heidegger, M. (2007). Nietzsche (Vol. 1 e 2). Rio de Janeiro: Forense Universitária.

Herrmann, F. (2001). Andaimes do real: o método da psicanálise. São Paulo: Casa do Psicólogo.

Herschmann, M. (2005). O funk e o hip hop invadem a cena. Rio de Janeiro: Ed. da UFRJ.

Hill, M. L. (2009). Beats, rhymes and classroomlife - hip-hop pedagogy and the politics of identity. New York:Teachers College, Columbia University.

Jovchelovitch, S. (2000). Vivendo a vida com os outros: intersubjetividade, espaço público e representações sociais. In P.Guaresch \& S. Jovchelovitch (Orgs.), Textos em representações sociais (pp. 63-85). Petrópolis, RJ:Vozes.

Machado, R. (1984). Nietzsche e a verdade. Rio de Janeiro: Rocco.

Milnitsky-Sapiro, C. (2006). Uma questão de método. (Trabalho não publicado)

Nakashima, E. Y. (2009). Reatando as pontas da rama: a inserção dos alunos da etnia Pankararu em uma escola pública na cidade de São Paulo. Dissertação de Mestrado, Faculdade de Educação, Universidade de São Paulo, São Paulo.

Nietzsche, F. (2004). Sobre o futuro de nossos estabelecimentos de ensino. In F. Nietzsche, Escritos sobre educação (pp. 41-137). Rio de Janeiro: Loyola. (Trabalho original apresentado como conferência em 1872)

Nietzsche, F. (2001). Além do bem e do mal. São Paulo: Companhia das Letras. (Trabalho original publicado em 1886)

Nietzsche,F.(2005a). A visão dionisíaca de mundo.São Paulo: Martins Fontes. (Trabalho original publicado em 1928)

Nietzsche, F.(2005b). Genealogia da moral. São Paulo: Companhia das Letras. (Trabalho original publicado em 1887)

Nietzsche, F. (2006). Crepúsculo dos ídolos. São Paulo: Companhia das Letras. (Trabalho original publicado em 1888)

Poetas do repente. (2008). Recife: Massangana. (Contém livro didático, DVD e CD de áudio) 
Racionais MC'S. (2002). Vida loka (Parte II). In Sobrevivendo no inferno [CD]. Manaus:Zambia Fonograifica.

Rodrigues, T. K. (2008). A metamorfose de jovens lideranças que querem ser professoras: como a escuta analítica propicia a potência crítica da práxis. Dissertação de Mestrado, Faculdade de Educação, Universidade de São Paulo, São Paulo.

Soares, L. E., Bill, M., \& Athayde, C. (2005). Cabeça de porco. São Paulo: L. E. Soares Criações. 
Mônica Guimarães Teixeira do Amaral, Docente da Faculdade de Educação da Universidade de São Paulo (FEUSP) e do Programa de Pós-Graduação em Educação da FEUSP, Membro Associado da Sociedade Brasileira de Psicanálise de São Paulo. Endereço para correspondência: Rua João Ramalho, 1074, apto 81, Perdizes. CEP: 05008002, São Paulo, SP, Brasil. Endereço eletrônico: monicagta@hotmail.com

Recebido: $21 / 06 / 2010$

Aceito: $28 / 01 / 2011$ 